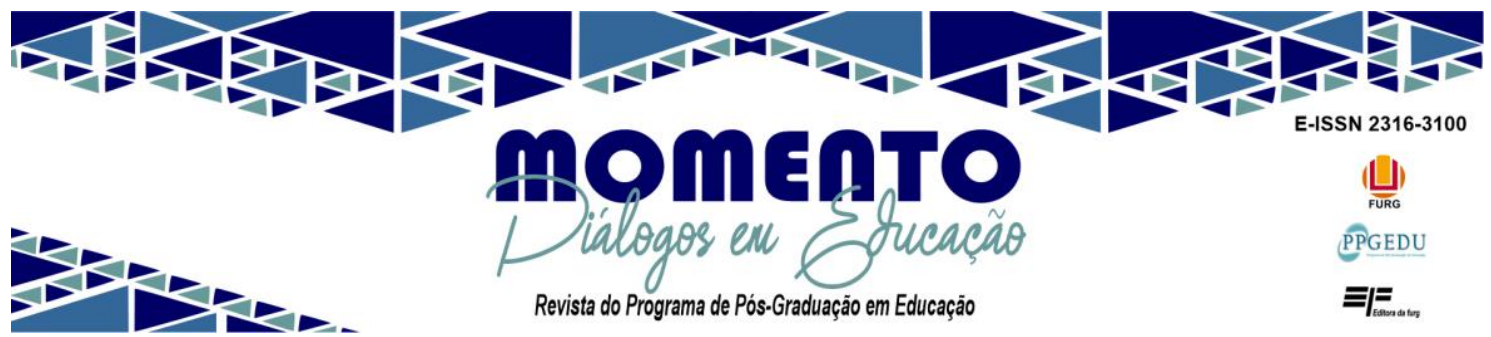

\title{
A PROBLEMÁTICA ACERCA DA INSERÇÃO PROFISSIONAL DOS LICENCIADOS EM EDUCAÇÃO DO CAMPO NA REDE PÚBLICA DE EDUCAÇÃO DO PARANÁ
}

\author{
Alex Verdério ${ }^{1}$ \\ Andreia Gomes Lima ${ }^{2}$
}

Resumo: Trata da inserção profissional de egressas e egressos do Curso de Licenciatura em Educação do Campo na rede pública estadual de educação do Paraná, e analisa a negação da atuação profissional desses sujeitos. A Educação do Campo é compreendida como conquista dos Movimentos Sociais, o que a coloca no âmbito de sua afirmação como política pública. Realizouse a análise da reivindicação acerca da inserção profissional de licenciados em Educação do Campo por áreas do conhecimento, voltando-se para algumas experiências de negação desse reconhecimento. Como procedimentos metodológicos, foram privilegiadas a pesquisa bibliográfica e a análise documental, com especial atenção para o Dossiê para Reconhecimento da Licenciatura em Educação do Campo, que foi organizado, no ano de 2017, pela Articulação Paranaense por uma Educação do Campo. No processo de pesquisa e análise, a mobilização e a organização foram verificadas como elementos centrais para garantia do direito dos povos trabalhadores do campo à educação. Isso se expande na luta pelo direito dos graduados em Educação do Campo para que possam exercer a profissão docente de acordo com o perfil de sua formação, buscando a conexão entre escola e vida como questão fundamental no delineamento e na afirmação da escola do campo.

Palavras-chave: Educação do Campo, Licenciatura em Educação do Campo, Inserção Profissional Docente.

\section{EL PROBLEMA SOBRE LA INSERCIÓN PROFESIONAL DEL LICENCIADO EN EDUCACIÓN DEL CAMPO EN LA RED DE EDUCACIÓN PÚBLICA DE PARANÁ}

Resumen: Trata de la inserción profesional de egresados de la Carrera de Licenciatura en Educación en Contexto Rural en la red pública estatal de educación de Paraná, y analiza la negación del ejercicio profesional de estos sujetos. La Educación en Contexto Rural es comprendida como un logro de los Movimientos Sociales, lo que la pone en el ámbito de su afirmación como política pública. Se realizó el análisis de la reivindicación acerca de la inserción profesional de licenciados en Educación en Contexto Rural por áreas del conocimiento, volcandose para algunas experiencias de negación de este reconocimiento. Como procedimiento metodológico se privilegió la investigación bibliográfica y el análisis documental, con especial atención al Dossier de reconocimiento de la Licenciatura en Educación en Contexto Rural, que

\footnotetext{
${ }^{1}$ Doutor em Educação (2018) pela Universidade Federal do Paraná (UFPR). Mestre em Educação (2011) e Licenciado em Pedagogia para Educadores do Campo (2008) pela Universidade Estadual do Oeste do Paraná (UNIOESTE). Especialista em Trabalho, Educação e Movimentos Sociais (2013) pela Escola Politécnica de Saúde Joaquim Venâncio (EPSJV-FIOCRUZ). É professor adjunto no Centro de Formação de Professores (CFP) da Universidade Federal do Recôncavo da Bahia (UFRB), onde atua como professor do Curso de Licenciatura em Educação do Campo - Ciências Agrárias, como coordenador do curso de Tecnologia em Agroecologia realizado na parceria com o Programa Nacional de Educação na Reforma Agrária (PRONERA) e como Coordenador Institucional do Programa Residência Pedagógica.

${ }^{2}$ Licenciada em Educação do Campo, Ciências Sociais e Humanas. Especialista em Educação do Campo e Realidade Brasileira. Professora na Escola Itinerante Herdeiros do Saber, Rio Bonito do Iguaçu-PR, com atuação nas séries iniciais do ensino fundamental.
} 


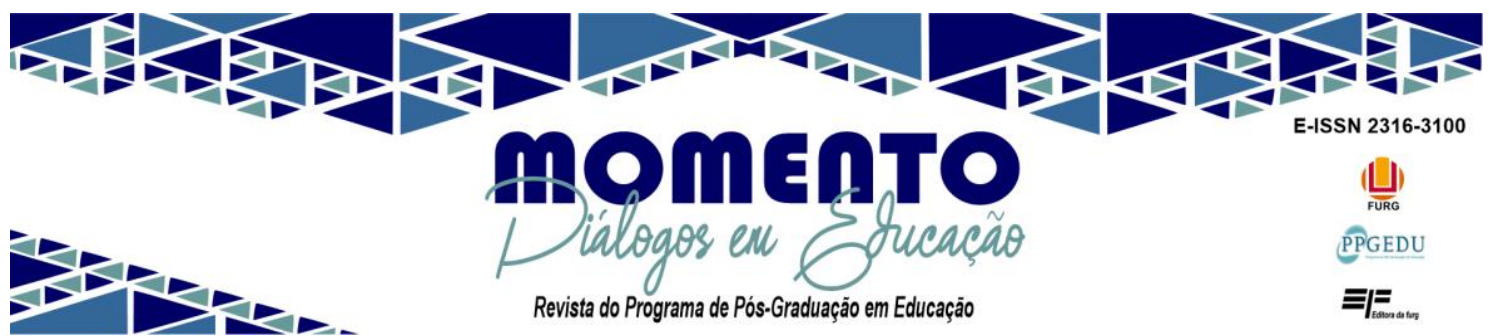

fue organizado en 2017, por la Articulación Paranaense de Educación en Contexto Rural. En el proceso de investigación y análisis, la movilización y la organización fueron verificadas como elementos centrales para garantía del derecho de los pueblos trabajadores del campo a la educación. Esto se expande por medio de la lucha por el derecho de los graduados en Educación en Contexto Rural para que puedan ejercer la profesión docente de acuerdo con el perfil de su formación, buscando la conexión entre la escuela y la vida como tema fundamental en el diseño y afirmación de la escuela en contexto rural.

Palabras-clave: Educación del Campo, Licenciatura en Educación del Campo, Inserción Profesional Docente.

\title{
THE EMPLOYABILITY PROBLEM OF RURAL AREA EDUCATION DEGREE HOLDERS IN THE PUBLIC EDUCATION SYSTEM OF PARANÁ STATE
}

\begin{abstract}
It deals with the professional insertion of Rural Area Education holders degree in the public education system of Paraná state, and analyzes the denial of the professional performance of these subjects. Rural Area Education is understood as an achievement of Social Movements, which places it within the scope of its affirmation as a public policy. The analysis about the professional insertion of graduates in Rural Area Education was carried out by areas of knowledge, turning to some experiences of denial of this recognition. As methodological procedures, bibliographic research and documentary analysis were prioritized, with special attention to the Recognition of the Degree in Rural Area Education Dossier, which was organized, in 2017, by The Paraná State Articulation for Rural Area Education. In the process of research and analysis, mobilization and organization were seen as central elements in guaranteeing the right of field workers to education. This expands in the struggle for the right of graduates in Rural Area Education so that they can exercise the teaching profession according to the profile of their education, seeking the connection between school and life as a fundamental concern in the design and affirmation of the rural school.
\end{abstract}

Keywords: Rural Area Education, Higher Education, Professional Practice, Teaching Entitlement.

\section{Introdução}

A pesquisa em questão propôs-se a sistematizar e a analisar alguns aspectos e desafios do Curso de Licenciatura em Educação do Campo no Estado do Paraná, sobretudo, vinculados à inserção profissional docente de egressas e de egressos do Curso na rede pública estadual de educação, concebendo-o no âmbito das políticas de inclusão na contemporaneidade.

A presente pesquisa buscou analisar quais são os principais desafios que licenciadas e licenciados em Educação do Campo, por áreas do conhecimento, estão enfrentando no que se refere a sua inserção profissional como docentes na rede pública 


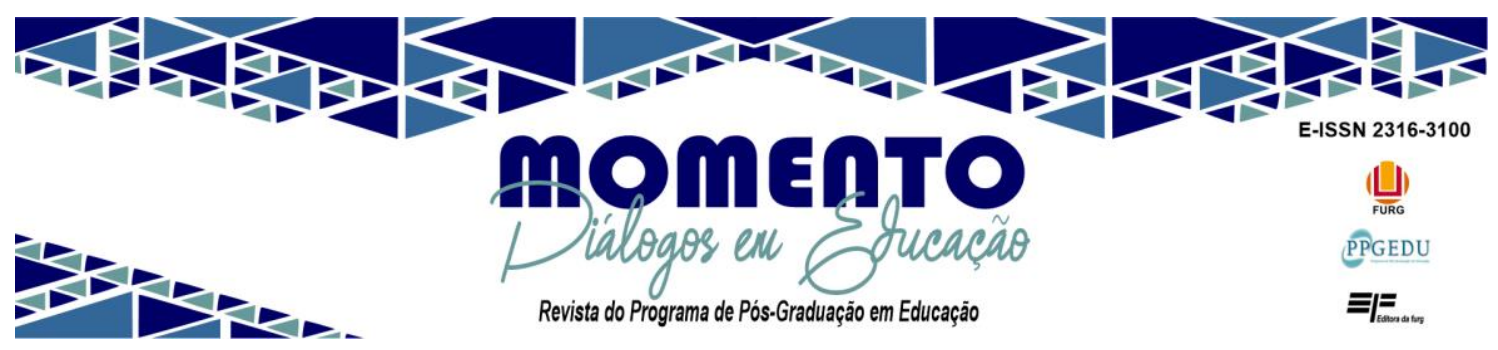

de educação, no Paraná. Para tanto, considera as especificidades acerca da formulação e do reconhecimento da política pública de Educação do Campo como um todo, e da própria formação propiciada na Licenciatura em Educação do Campo. Assim, é possível compreender que a Educação do Campo e o Curso posto em evidência colocam-se como questões paradigmáticas no contexto educacional brasileiro e no âmbito das políticas públicas, tendo possibilitado, mesmo que de maneira mediatizada e relativa, a inclusão dos setores populares no debate e a efetivação do direito à educação em nossa contemporaneidade. Contudo, cabe destacar as fragilidades desse processo, o que, no caso aqui posto, reflete-se no não reconhecimento da formação propiciada por áreas de conhecimento, o que, por sua vez, vincula-se a resquícios de processos de exclusão historicamente vivenciados pelos povos trabalhadores do campo.

O trabalho em questão foi estruturado a partir da pesquisa de caráter bibliográfico, o que possibilitou o aporte de autores que analisam e que contribuem com as formulações da Educação do Campo em sua materialidade de origem. Contou com a análise documental de editais, e com outros documentos que tratam da questão assumida como problemática de pesquisa, seja ela a inserção profissional docente de egressas e de egressos do Curso de Licenciatura em Educação do Campo no Paraná.

Dentre os materiais considerados na pesquisa documental, destaca-se o Dossiê para Reconhecimento da Licenciatura em Educação do Campo, que foi organizado pela Articulação Paranaense por uma Educação do Campo, e tem sido assumido como subsídio na reivindicação do reconhecimento da titularidade das licenciadas e dos licenciados pelo Curso no Paraná. Esse dossiê foi organizado a partir de um conjunto de documentos e é constituído, dentre outros, pela Carta de Reconhecimento das Licenciaturas em Educação do Campo (UFPR et al., 2017), pelo Edital nº 017/2013 (PARANÁ, 2013), pela Nota Técnica Conjunta n 3/2016 (SANTA CATARINA, 2016) e pela Resolução de reconhecimento da Educação do Campo como Política Pública no Paraná (PARANÁ, 2010). Incluem-se, ainda, nos documentos analisados, o Edital nº 72/2017-GS-SEED, de 15 de dezembro de 2017 (PARANÁ, 2017), o Edital nº 57/2018 - GS/SEED, de $1^{\circ}$ de outubro de 2018 (PARANÁ, 2018), e a Ata nº 01/2018, da Audiência Pública dos Cursos de Licenciaturas em Educação do Campo, realizada em 28 de junho de 2018, na UFFS Campus Laranjeiras do Sul (UFFS, 2018). 


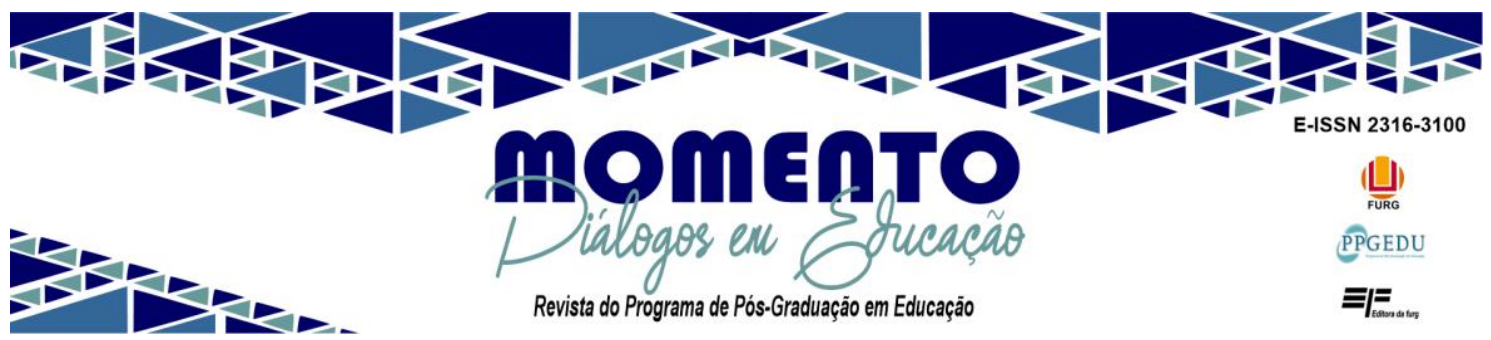

De acordo com a Carta de Reconhecimento das Licenciaturas em Educação do

Campo (UFPR et al., 2017), cinco Universidades públicas, tanto de nível Federal como

Estadual, no Estado do Paraná, ofertam ou ofertaram o Curso de Licenciatura em Educação do Campo, nas mais variadas áreas de conhecimento - Ciências Agrárias, Ciências da Natureza, Ciência Sociais e Humanas, Matemática e Linguagens. O Curso está ou esteve presente na Universidade Federal do Paraná (UFPR), Setor Litoral, na Universidade Federal da Fronteira Sul (UFFS), Campus Laranjeiras do Sul, na Universidade Tecnológica Federal do Paraná (UTFPR), Campus Dois Vizinhos, na Universidade Estadual do Oeste do Paraná (UNIOESTE), Campus Cascavel, e na Universidade Estadual do Centro Oeste (UNICENTRO), Campus Santa Cruz, em Guarapuava.

Para refletir as várias questões que perpassam a problemática da inserção profissional docente de egressas e egressos da Licenciatura em Educação do Campo, no Estado do Paraná, faz-se necessário considerar o momento histórico de sérios retrocessos vivenciados na educação pública nos últimos anos, refletido na desqualificação de sua referência e concretização na esfera pública e concomitante mercantilização. Isso se processa, também, no que diz respeito à Educação do Campo, o que se contrapõe a sua materialidade de origem. De acordo com Caldart (2008),

O conceito de Educação do Campo como parte da construção de um paradigma teórico e político não é fixo, fechado, também não pode ser aleatório, arbitrário: qualquer um inventado por alguém, por um grupo, por alguma instituição, por um governo, por um movimento ou organização social. Pelo nosso referencial teórico, o conceito de Educação do Campo tem raiz na sua materialidade de origem e no movimento histórico da realidade a que se refere. Essa é a base concreta para discutirmos o que é ou não é a Educação do Campo. Educação do Campo é um conceito em movimento como todos os conceitos, mas ainda mais porque busca apreender um fenômeno em fase de constituição histórica; por sua vez, a discussão conceitual também participa deste movimento da realidade. Trata-se, na expressão do Professor Bernardo Mançano, de uma disputa de "território imaterial", que pode em alguns momentos se tornar força material na luta política por territórios muito concretos, como o destino de uma comunidade camponesa, por exemplo (CALDART, 2008, p. 69-70). 


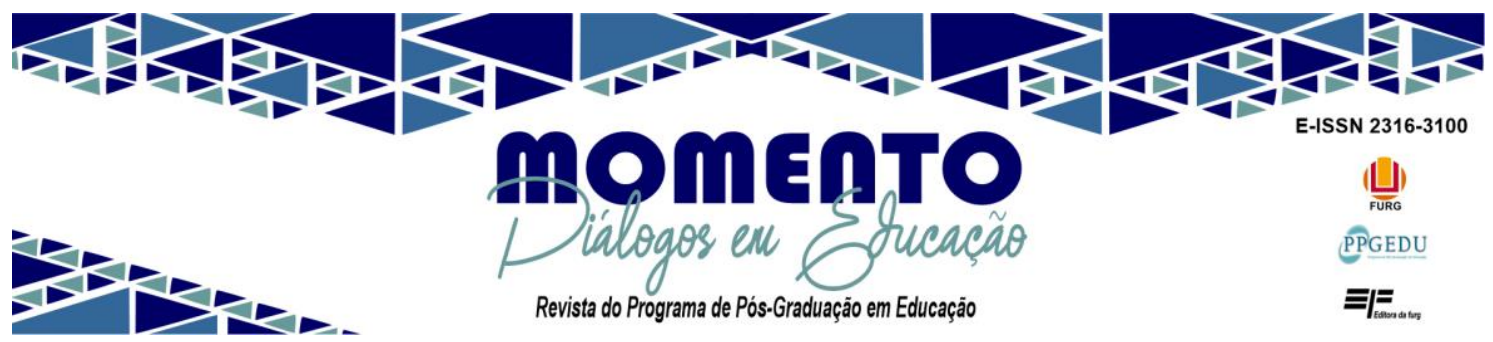

Congruente com tal perspectiva, aponta-se a necessidade de verificar, reivindicar, problematizar e afirmar a própria materialidade de origem da Educação do Campo e sua incidência no âmbito da política pública, que tem como uma de suas conquistas a constituição de um marco normativo na legislação educacional que, dentre outros, dá amparo legal para a atuação das licenciadas e dos licenciados em Educação do Campo. Assim, para além do diploma e da formação profissional, política e pedagógica propiciadas pelo Curso, coloca-se a necessidade de reafirmar os documentos que asseguram o direito do exercício pleno da profissão docente desses sujeitos.

Problematizar e aprofundar a compreensão acerca dessas questões é algo pertinente à concretização da Educação do Campo como direito, principalmente, nesse momento histórico perpassado por uma crise profunda do capital, na qual a negação de direitos coloca-se como premissa para a manutenção da reprodução ampliada de capitais. Nesse sentido, afirma-se a relevância do presente estudo, por se tratar de uma problemática social, política e econômica ancorada na luta por uma Educação do Campo como um todo.

[...] compreende-se como luta por uma Educação do Campo a articulação de diversos sujeitos comprometidos com a educação dos povos trabalhadores do campo no Brasil, tendo como elemento central os sujeitos a que se refere como protagonistas na proposição e na realização de uma educação que atenda seus interesses e, estando conectada a processos educacionais contra-hegemônicos, se coloca na perspectiva da transformação social e da emancipação humana.

Assim, a luta por uma Educação do Campo parte da própria diversidade dos sujeitos trabalhadores do campo no Brasil e das práticas e perspectivas educativas forjadas nas lutas sociais de tais sujeitos. A luta por uma Educação do Campo se faz diversa na unidade de classe. Não é homogênea e nem uniforme, mas possui uma materialidade de origem que a identifica e lhe confere unidade (VERDÉRIO, 2018, p. 66-67).

Ao considerar a constituição conceitual da Educação do Campo, verifica-se que ela é traduzida na figuração do paradigma da Educação do Campo (SANTOS, 2012). De acordo com tal análise, possível identificar que, ao longo de sua trajetória, a Educação do Campo construiu um caminho que esteve relacionado à luta pelo direito à educação, sendo concebida, inclusive, como política pública. Nesse contexto, Molina (2010) destaca que a Educação do Campo, no que diz respeito à formação de educadoras e 


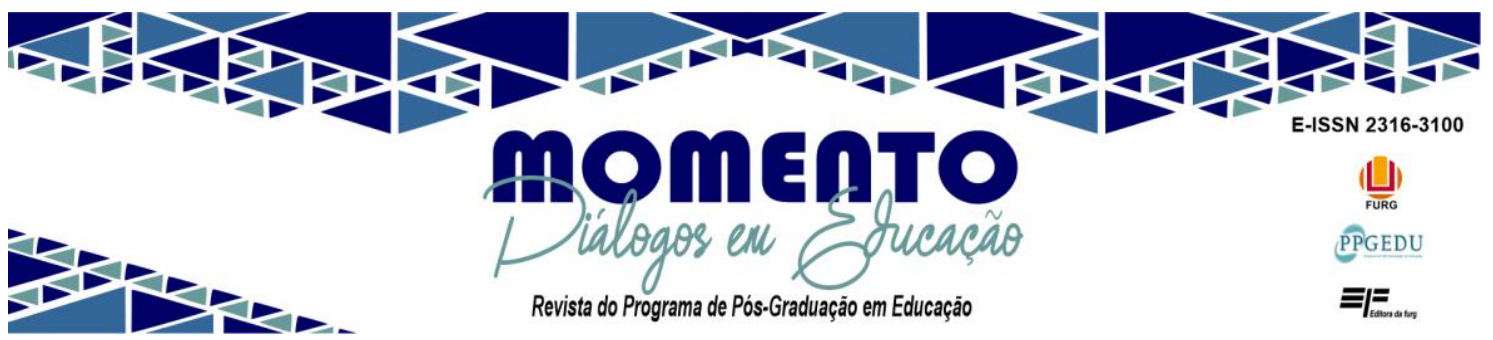

educadores se materializou, dentre outras, por meio do Programa de Apoio à Formação

Superior em Licenciatura em Educação do Campo (PROCAMPO). Sendo que, no que tange à Educação Superior, além da atuação incisiva dos Movimentos Sociais e Organizações Populares do Campo, esse processo contou com o apoio de educadoras e educadores, gestoras e gestores de políticas e processos educacionais que já possuíam certa experiência com Cursos de Pedagogia da Terra, realizados na parceria com o Programa Nacional de Educação na Reforma Agrária (PRONERA).

Dessa forma, a Licenciatura em Educação do Campo está diretamente ligada a uma necessidade material, voltada para a formação de educadoras e educadores que estejam aptos para atuar nos anos finais do Ensino Fundamental e no Ensino Médio nas escolas do campo. Para tanto, o Curso, em suas diferentes configurações e no conjunto das Instituições de Educação Superior, passa a estar organizado a partir da formação por áreas do conhecimento e a ser ofertado em regime de alternância, no sentido de promover a

[...] habilitação para docência multidisciplinar nos anos finais do ensino fundamental e no ensino médio em uma das áreas do conhecimento: linguagens e códigos, ciências humanas, ciências da natureza, matemática e ciências agrárias. A proposta pedagógica de formação do PROCAMPO, construída com a participação social, tem como base a realidade dos povos do campo e quilombola e a especificidade da organização e oferta da educação básica às comunidades rurais. (BRASIL, 2021).

De acordo com Molina e Antunes-Rocha (2014, p. 230), o regime de alternância, constituído por

períodos de aprendizagem integrados entre Tempo Escola, nas Universidades públicas e Tempo Comunidade, que ocorre nas áreas rurais de origem destes educandos, objetiva não só evitar que o ingresso de jovens e adultos na educação superior reforce a alternativa de deixar de viver no campo, bem como objetiva promover a articulação entre educação e a realidade específica destas populações, possibilitando uma leitura crítica que, a partir dessa realidade, seja capaz de perceber as determinações sociais que assim a produzem, considerando a totalidade maior que a contém. 


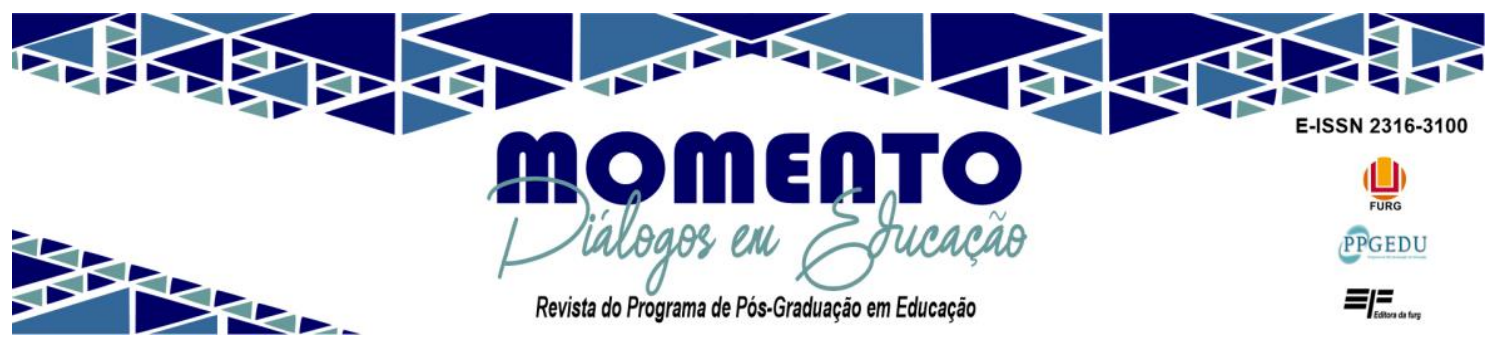

Assim, o regime de alternância como elemento estruturante da Licenciatura em Educação do Campo está sustentado “[...] na própria origem do sujeito que frequentará o curso - trabalhador ou trabalhadora do campo. Esta condição exige uma estrutura diferenciada para permitir sua vinda ao espaço em que se realiza o curso e, ao mesmo tempo, viabilizar sua permanência nele.” (VERDÉRIO, 2018, p. 113). Isso tem possibilitado a realização de processos formativos voltados para qualificar a educadora e o educador que já vêm desenvolvendo trabalho junto às comunidades do campo, mas que ainda não possuem a formação e a certificação necessárias para o exercício dessa função.

Desse modo, a formação da educadora e do educador, licenciada e licenciado em Educação do Campo, passa por impulsionar o engajamento político nos diferentes Movimentos Sociais e Organizações Populares do Campo e na própria luta por uma Educação do Campo, o que volta-se, também para o debate e para a construção da escola do campo.

\begin{abstract}
As escolas do campo demandada pelos movimentos vai [sic] além da escola das primeiras letras, da escola da palavra, da escola dos livros didáticos. É um projeto de escola que se articula com os projetos sociais e econômicos do campo, que cria uma conexão direta entre formação e produção, entre educação e compromisso político. Uma escola que, em seus processos de ensino e de aprendizagem, considera o universo cultural e as formas próprias de aprendizagem dos povos do campo [...] (SANTOS, 2012, p. 73).
\end{abstract}

Assim, ao pensar em um novo tipo de escola, faz-se necessário pensar a formação deste educador que irá atuar nestas escolas. Dessa forma, a formação da licenciada e do licenciado em Educação do Campo, efetivada por áreas de conhecimento, está diretamente ligada com esta nova proposta de escola produzida na luta por uma Educação do Campo.

Em nossa atualidade, vivemos em um período crítico na história, marcada pelo acirramento da luta de classes, no qual o projeto de Educação de Campo, aqui afirmado, conecta-se aos anseios da classe trabalhadora camponesa. Porém, contraditoriamente, como dito anteriormente, neste contexto de crise, a tendência geral é a de negação dos direitos da população em todas as dimensões, o que passa pela negação do direito dos povos trabalhadores do campo à educação. 


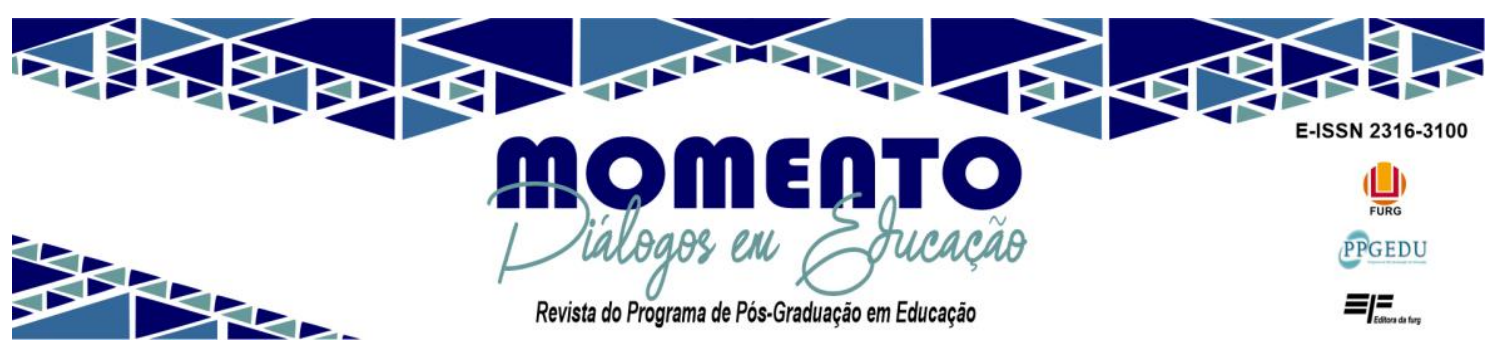

No que se refere ao objeto de estudo, aprofundamento e teorização assumido - o

Curso de Licenciatura em Educação do Campo -, destaca-se a pertinência da análise sobre os limites relacionados ao seu reconhecimento no Paraná, com foco voltado para o não reconhecimento da formação em Educação do Campo por área de conhecimento na rede pública estadual de educação. Para tanto, o presente trabalho firma-se em algumas posições que expressam o não reconhecimento dos diplomas em Educação do Campo pela Secretaria Estadual de Educação do Estado do Paraná (SEED-PR).

Essa impossibilidade da atuação profissional docente de egressas e egressos do Curso no Paraná, de acordo com a Carta de reconhecimento das Licenciaturas em Educação do Campo (UFPR et al., 2017), foi expressa, num primeiro momento, no caso de quatro licenciados pelo Curso ofertado na UNICENTRO que passaram no concurso público sob responsabilidade da SEED-PR (PARANÁ, 2013), mas que foram impedidos de assumir o cargo para o qual foram aprovados.

De modo geral, os processos vivenciados quanto ao não reconhecimento do diploma da Licenciatura em Educação do Campo no referido concurso público realizado no Paraná (PARANÁ, 2013) permitem compreender que esta problemática nada mais é que a negação do direito do exercício da profissão pelo próprio Estado, que oferta a formação por área de conhecimento nas Universidades públicas Estaduais e Federais.

A elaboração do presente trabalho esteve vinculada a uma atividade do curso lato sensu de Especialização em Realidade Brasileira, da UFFS Campus Laranjeiras do Sul. O referido curso colocou-se como uma demanda dos Movimentos Sociais e Organizações Populares do Campo junto às Universidades, que se propõem a pensar e entender a realidade brasileira neste momento histórico. Por isso, as bases filosóficas e sociológicas discutidas no curso foram assumidas como referências indiretas para analisar e enfrentar os desafios que se apresentam nos dias atuais, no caso aqui posto, a negação da atuação do profissional docente graduado em Educação do Campo, com habilitação por áreas de conhecimento.

Nesse sentido, justifica-se a importância deste trabalho, o qual faz parte de uma demanda atual, que é o reconhecimento pleno das Licenciaturas em Educação do Campo, para que assim, licenciadas e licenciados em Educação do Campo por áreas de conhecimento, possam exercer o seu direito de atuação profissional como docentes da Educação Básica do Campo nas redes públicas de educação. 


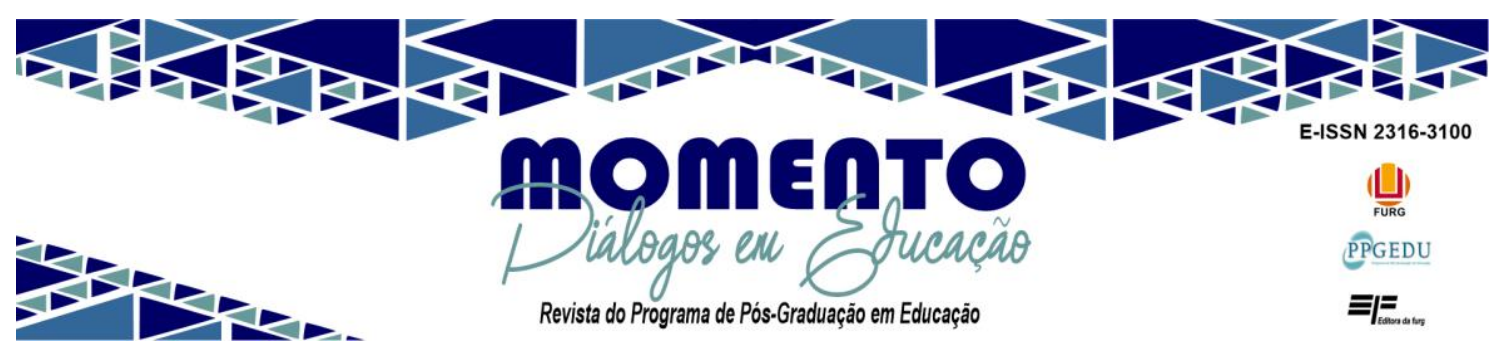

A Educação do Campo e a Licenciatura em Educação do Campo no Paraná

De acordo com Stédile (2005) e Fernandes (1998), o Brasil é um país basicamente agrário, latifundiário e agroexportador, pautado na subordinação dos trabalhadores do campo e da cidade em favor do lucro dos grandes capitalistas, dentre eles, os empresários do agronegócio.

O Brasil, já em sua gênese, a partir da sujeição aos interesses do capital internacional, coloca-se no cenário internacional como mero produtor e fornecedor de matérias-primas para as grandes potências capitalistas, sobretudo, a partir da exploração de seus recursos naturais e da produção agrícola em seu território. Porém, durante toda sua história, o país foi e é marcado por fortes embates e disputas entre as classes sociais antagônicas no campo: de um lado, o grande latifundiário capitalista e, do outro, a classe trabalhadora camponesa.

Nesse contexto contraditório do campo brasileiro, eivado pela luta de classes, foi forjado, em 1984, o MST, que se coloca, de maneira inequívoca, contra o latifúndio e contra o Estado, com suas reivindicações, protestos e mobilizações, traduzidas, principalmente, na ocupação da terra. Molina (2010) acrescenta, ainda, que, além da luta pela terra, protagonizada pelo MST, tem-se outros Movimentos Sociais e Organizações Populares do Campo, tais como: o Movimento dos Atingidos por Barragens (MAB), os Ribeirinhos, os Indígenas, entre outros, que realizam processos de lutas contra o latifúndio, pelo acesso à terra e, também, pela educação.

Assim, ao considerar os vários processos de luta desencadeados pelos povos trabalhadores do campo no Brasil (MOLINA, 2010), verifica-se que, junto a isso, se coloca a necessidade de uma educação diferenciada e que esteja articulada aos processos de luta pela terra. Nesse quadro, ainda no ano de 1997, no I Encontro Nacional de Educadores e Educadoras da Reforma Agrária (I ENERA), foi forjado o conceito de Educação do Campo no Brasil. “A Educação do Campo é resultado, das contradições existentes historicamente no Brasil, portanto ela se materializou como resultado da luta de classes. É consequência do próprio movimento do real, da realidade em que viviam e vivem os sujeitos do campo" (LIMA, 2017, p. 17).

Segundo Kuhn (2015), a Educação do Campo, no que diz respeito ao conteúdo e 


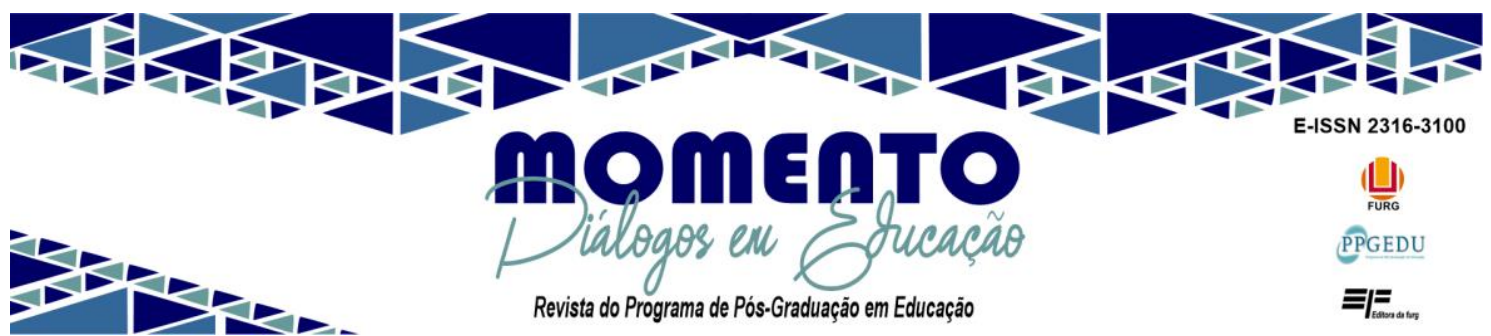

à forma, para constituir-se na perspectiva contra-hegemônica, necessita estar pautada na autonomia dos Movimentos Sociais e nas Organizações Populares do Campo. Todavia, no fazer histórico da Educação do Campo e em consonância com sua materialidade de origem, uma compreensão tem sido afirmada, a qual indica para a necessidade contínua da reivindicação e luta por exigir do Estado o financiamento público para sua realização. Nesse aspecto, Kuhn (2015) argumenta que a Educação do Campo, dentre outros elementos, passa pela disputa da política pública. Assim, afirma-se o paradigma da Educação do Campo como um fenômeno econômico, social, político e pedagógico que considera as múltiplas dimensões que a constituem.

Ao afirmar a necessidade de análise da temática e da problemática acerca da inserção de egressas e egressos do Curso de Licenciatura em Educação do Campo no Paraná, pontua-se que essa opção de estudo está diretamente ligada com a vida dos povos trabalhadores do campo (Sem Terra, Indígenas, Posseiros, Atingidos por Barragem, dentre outros), no sentido de discutir e reivindicar o direito à Educação do Campo. Isso se vincula à possibilidade e à luta por uma melhor qualidade de vida, por uma escola que compreenda o ser humano nas suas várias dimensões, afirmando o direito de acesso à terra, ao trabalho e ao conhecimento, na perspectiva de viabilizar a produção de alimentos saudáveis, compreendendo o campo como lugar de vida e de relações.

No Paraná, em decorrência dos três editais do PROCAMPO publicados nos anos de 2008, 2009 e 2012, o Curso de Licenciatura em Educação do Campo já foi ofertado em duas Universidades Estaduais e, atualmente, é ofertado em três Universidades Federais. De acordo com essa configuração do PROCAMPO e conforme o Quadro 1, apresentado na sequência, nas cinco Universidades públicas já mencionadas, localizadas no Paraná, entre os anos de 2009 e 2019, o Curso de Licenciatura em Educação do Campo já graduou 227 licenciadas e licenciados em Educação do Campo, em distintas áreas do conhecimento. 


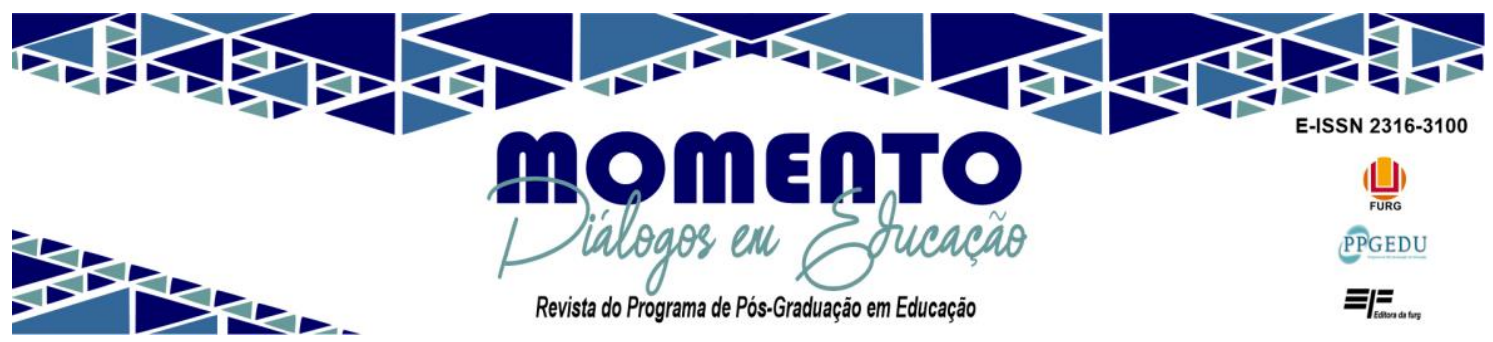

Quadro 1 - Egressos do Curso de Licenciatura em Educação no Campo no Paraná 2009 - 2019

\begin{tabular}{|c|c|c|c|}
\hline Universidade & Período & $\begin{array}{l}\text { Curso / Área de } \\
\text { Conhecimento }\end{array}$ & Número de Egressos \\
\hline UNIOESTE & $2010-2014$ & $\begin{array}{c}\text { Licenciatura em } \\
\text { Educação do Campo: } \\
\text { Ciências da Natureza, } \\
\text { Matemática e Ciências } \\
\text { Agrárias }\end{array}$ & 46 \\
\hline UNICENTRO & $2009-2013$ & $\begin{array}{c}\text { Licenciatura em } \\
\text { Educação do Campo: } \\
\text { Ciências da Natureza, } \\
\text { Matemática e Ciências } \\
\text { Agrárias e Linguagens }\end{array}$ & 34 \\
\hline UTFPR & $2009-2014$ & $\begin{array}{c}\text { Licenciatura em } \\
\text { Educação do Campo: } \\
\text { Ciências da Natureza, } \\
\text { Matemática e Ciências } \\
\text { Agrárias }\end{array}$ & 22 \\
\hline \multirow[b]{2}{*}{ UFFS } & $2012-2019$ & $\begin{array}{c}\text { Interdisciplinar em } \\
\text { Educação do Campo: } \\
\text { Ciências Sociais e } \\
\text { Humanas }\end{array}$ & 36 \\
\hline & $2009-2019$ & $\begin{array}{c}\text { Interdisciplinar em } \\
\text { Educação do Campo: } \\
\text { Ciências da Natureza, } \\
\text { Matemática e Ciências } \\
\text { Agrárias }\end{array}$ & 37 \\
\hline UFPR & $2014-2018$ & $\begin{array}{c}\text { Licenciatura em } \\
\text { Educação do Campo: } \\
\text { Ciências da Natureza }\end{array}$ & 52 \\
\hline & & Total de Egressos & 227 \\
\hline
\end{tabular}

Fonte: Quadro elaborado a partir de Verdério et al. (2019).

Assim, a análise sobre a inserção profissional docente de licenciadas e licenciados em Educação do Campo por áreas de conhecimento no Paraná se faz necessária. Parafraseando Caldart (2009), a expansão das Licenciaturas em Educação do Campo é um fenômeno complexo de se analisar, porém necessário, que compreende a inserção dos profissionais egressos dos Cursos em Educação do Campo.

De acordo com Farias e Faleiro (2017), a Educação do Campo se materializa articulada à luta pela terra protagonizada pelos Movimentos Sociais e Organizações Populares do Campo e somente mais tarde, no final da década de 1990, é que ela incide e é reconhecida no âmbito das políticas públicas. Conforme Kuhn (2015), esse processo de institucionalização da Educação do Campo se dá, primeiramente, via o PRONERA, 


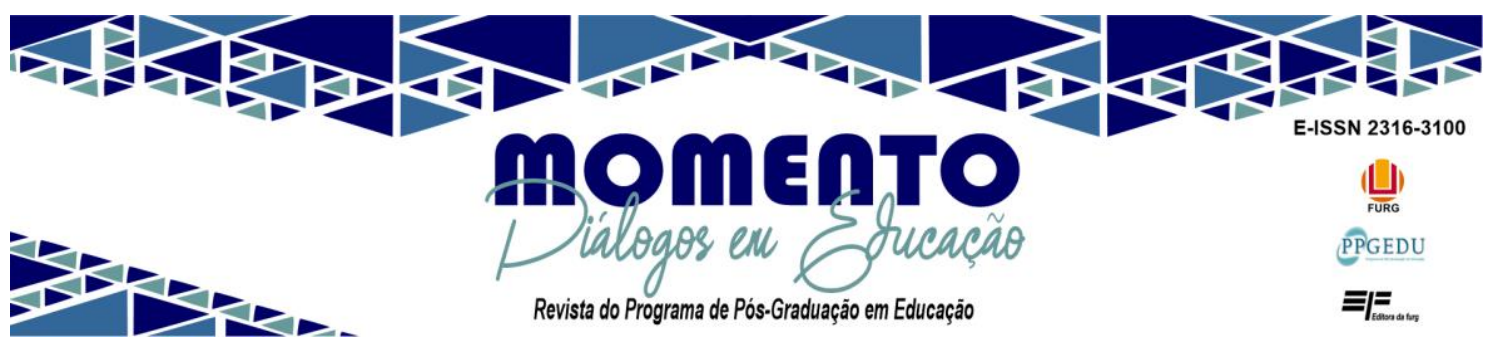

criado em 1998. Já em 2006, esse processo se amplia por meio do PROCAMPO e, posteriormente, em 2012, toma maior envergadura com o Programa Nacional de Educação do Campo (PRONACAMPO) (KUHN, 2015).

No Paraná, com exceção do curso Interdisciplinar em Educação do Campo: Ciências da Natureza, Matemática e Ciências Agrárias - Licenciatura, ofertado pela UFFS, Campus Laranjeiras do Sul, todos os demais Cursos foram e são ofertados no regime de alternância que, como dito, é estruturado na articulação entre o tempo na Universidade e, em um segundo momento, na comunidade em que os acadêmicos residem, portanto é uma forma de articular teoria e prática em um movimento contínuo de práxis.

\section{A problemática sobre a inserção profissional docente de licenciadas e licenciados em Educação do Campo na rede pública estadual de educação do Paraná}

Como já afirmado, a Educação do Campo é uma conquista dos Movimentos Sociais e Organizações Populares do Campo e, no decorrer desse processo, este paradigma obteve grandes avanços, dentre eles, a conquista do Curso de Licenciatura em Educação do Campo.

De acordo com Kuhn (2015), a Educação do Campo, ao adentrar no âmbito das políticas públicas, pela força e pela capacidade de mobilização e de luta dos Movimentos Sociais e das Organizações Populares do Campo, assume, como uma de suas reivindicações, a formação de educadoras e educadores para atuarem nas escolas do campo.

Contudo, nos últimos períodos, verifica-se um momento conturbado na luta da classe trabalhadora, refletido, sobretudo, em uma maior hegemonia da classe dominante com o fortalecimento de processos conservadores e de exclusão no conjunto da sociedade brasileira e com o estabelecimento de um projeto ultraneoliberal e fundamentalista gerido pelo Estado Maior do Capital e que sustenta o atual governo (LEHER, 2020, p. 109). Um momento de retrocessos, inclusive na educação, pois o que está em jogo são projetos de classes sociais antagônicas; de um lado, os trabalhadores e, de outro, a pequena parcela da sociedade que se constitui a partir da propriedade dos meios de produção.

A partir dos anos 2000, foram vários os avanços na educação brasileira, com um 


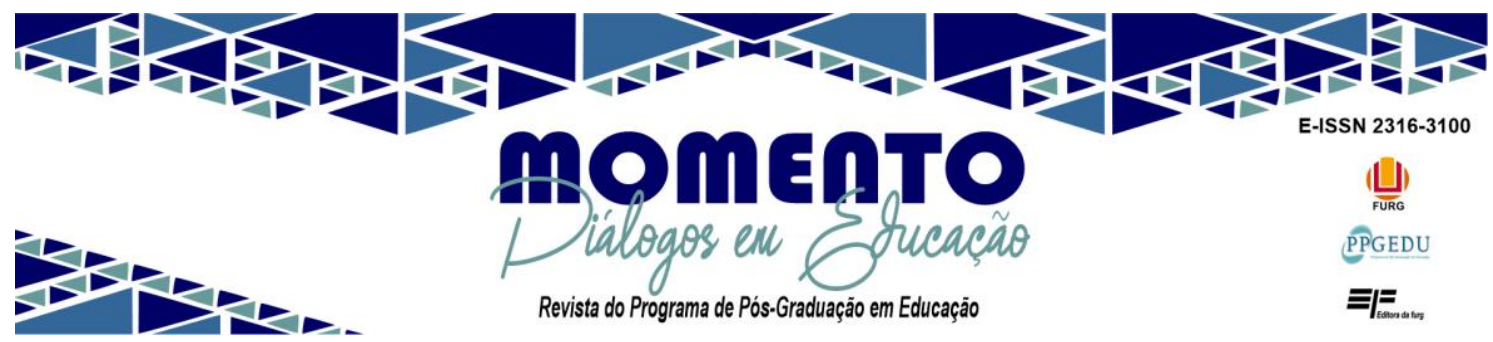

importante processo de interiorização das Universidades públicas no país, o que resultou na criação de novas instituições, entre elas, a própria UFFS. Outra importante conquista para a educação foi a criação da Secretaria de Educação Continuada, Alfabetização, Diversidade e Inclusão (SECADI) no âmbito do Ministério da Educação (MEC), tendo, como função primordial, garantir o direito de todos à educação, com qualidade e equidade, permitindo, assim, a diversidade de povos a terem acesso a políticas públicas educacionais- (MEC, 2019), dentre eles, os povos trabalhadores do campo ${ }^{3}$.

$\mathrm{Na}$ contramão desse processo, atrelado ao debate e à conjuntura da educação pública no Brasil, poderiam ser enumerados, aqui, os vários retrocessos tidos nos últimos anos. Contudo, destaca-se que, nesse contexto de retrocessos, os impedimentos postos para egressas e egressos do Curso de Licenciatura em Educação no Campo, quanto a sua inserção profisssional docente, na rede pública estadual de educação, no Paraná, é uma das questões que tem repercutido de maneira negativa junto a tais sujeitos e à luta por uma Educação do Campo como um todo.

Diante deste contexto, as Universidades públicas, os acadêmicos, os egressos, juntamente com a Articulação Paranaense por uma Educação do Campo, organizaram audiências públicas no Estado do Paraná para problematizarem a questão e cobrarem providências da SEED-PR quanto ao reconhecimento da formação por áreas de conhecimento. Nas audiências públicas, dentre outros, foi reivindicada a consideração da titularidade em Licenciatura em Educação do Campo, por áreas de conhecimento nos editais sob responsabilidade da SEED-PR.

Na noite do dia 28/06/2018, foi realizada audiência pública para debater a carreira profissional dos licenciados em Educação do Campo, sediada na Universidade Federal da Fronteira Sul - UFFS - Campus Laranjeiras do Sul. Contou com a participação de representantes do Núcleo Regional de Educação, Estudantes do Curso, Pró reitor de Graduação da UFFS, Ministério Público, Representante da Universidade Estadual do Centro Oeste do Paraná - UNICENTRO, Ceagro - Centro de Desenvolvimento e Capacitação em Agroecologia. A audiência teve como debate central a discussão quanto ao reconhecimento da carreira dos Licenciados, uma vez que os Cursos foram ofertados pelas Universidades, reconhecidos pelo Ministério da Educação, e pelo conselho estadual de educação do Paraná, e os

\footnotetext{
${ }^{3}$ Em 2 de janeiro de 2019, por meio do Decreto n ${ }^{\circ}$ 9.465, a SECADI foi extinta.
} 


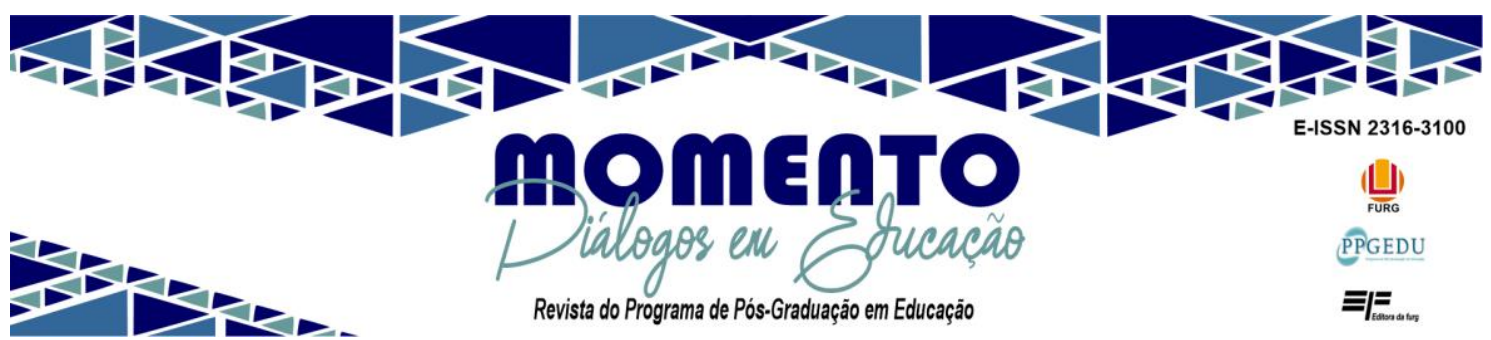

egressos devidamente diplomados. Denúncias foram feitas baseadas em ocorrência em processos de Contratação de Professores temporários e em Concurso Público no Estado do Paraná, uma vez que a SEED Não reconhece a carreira e os diplomas dos formados nas Licenciaturas em Educação do Campo. Ao final da Audiência foi elaborada uma ata a qual relata as denúncias que serão encaminhadas a Articulação Paranaense por uma Educação do/no Campo, a qual vem mobilizando e articulando forçar para o reconhecimento da carreira dos licenciados: (CEAGRO, 2018, p. 1.).

De acordo com a Carta de Reconhecimento das Licenciaturas em Educação do Campo (UFPR et al., 2017) e a Ata nº 01/2018 (UFFS, 2018), o Estado do Paraná, representado pela SEED-PR, tem dificultado e, em certos momentos, negado o reconhecimento dos diplomas de egressas e egressos do Curso de Licenciatura em Educação do Campo por área de conhecimento.

O descaso por parte do Estado tem sido refletido na inferiorização e na não aceitação do diploma em Educação do Campo por área de conhecimento. Esses processos foram evidenciados na Audiência Pública dos Cursos de Licenciaturas em Educação do Campo, realizada em 28 de junho de 2018, na UFFS, Campus Laranjeiras do Sul. Isso foi expresso na exposição de uma das egressas do Curso da UNICENTRO que foi impedida de assumir o concurso público realizado no Paraná (PARANÁ, 2013). De acordo com registro sistematizado na Ata $\mathrm{n}^{\circ}$ 01/2018,

[...] desde dois mil e nove não são reconhecidos os diplomas dos egressos [...] O primeiro processo seletivo em dois mil e onze não constou a educação do campo nos editais. No concurso público realizada em dois mil e treze, após ser aprovada em todas as etapas, seu diploma não foi aceito para tomar posse. A egressa relata que no Núcleo Regional de Educação de Laranjeiras do Sul nem avaliou o diploma, por ser de licenciatura em educação do campo. A egressa seguiu seu relato questionando: se o diploma é de universidade estadual porque não posso ser professora concursada no estado? Já no processo seletivo PSS o diploma foi aceito; informou ainda que sentiu humilhada pela situação de ser discriminada no Núcleo Regional de Educação [...]. (UFFS, 2018, p. 1-2).

Como pode ser verificado no relato da egressa do Curso da UNICENTRO, a dificuldade de inserção profissional de licenciadas e de licenciados em Educação do Campo é uma realidade, evidenciada, sobretudo, pela não aceitação dos diplomas de 


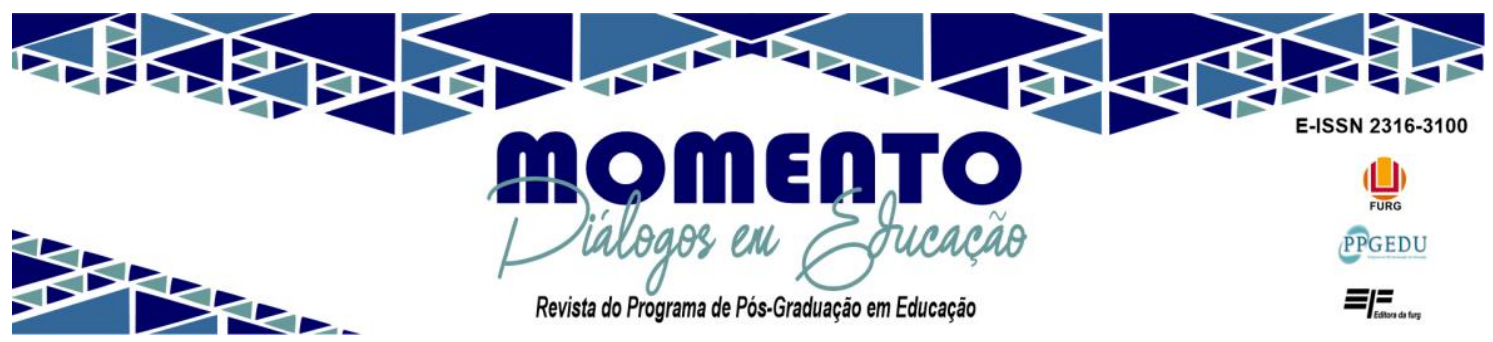

professores egressos formados nos Cursos de Licenciatura em Educação do Campo, no Paraná e, nesse caso em específico, no Curso ofertado pela UNICENTRO.

Além dos quatro aprovados no concurso de 2013, que não puderam assumir o cargo, outro exemplo pertinente foi o caso de uma licenciada, formada em 2017 e egressa do Curso Interdisciplinar em Educação do Campo: Ciências Sociais e Humanas Licenciatura da UFFS, Campus Laranjeiras do Sul, impedida de assumir aulas no município onde reside. Nesse caso, a egressa da Licenciatura em Educação do Campo teve que buscar amparo por meio de um mandado de segurança, que, num primeiro momento, lhe garantiu o direito de assumir as aulas na rede pública estadual de educação.

Destaca-se que, em ambos os casos, nos quais as egressas e os egressos tiveram seu direito de atuação profissional negado pelo Estado, tais sujeitos obtiveram o grau de licenciadas e licenciados em Educação do Campo, com habilitação para atuarem nos anos finais do Ensino Fundamental e no Ensino Médio nas escolas do campo, considerando as áreas de conhecimento pertinentes ao curso.

Conforme informações que foram apresentadas anteriormente - dispostas no Quadro 1: Egressos do Curso de Licenciatura em Educação do Campo no Paraná 2009 2019 -, no caso da UNICENTRO, a Licenciatura em Educação do Campo habilitou para atuar nas áreas de conhecimento de Ciências da Natureza e Matemática, Ciências Agrárias ou Linguagens. Já no caso da UFFS, o curso habilita para atuação profissional na área das Ciências Sociais e Humanas.

Congruente com essa disposição proposta no perfil formativo de cada Curso, a Lei de Diretrizes e Bases da Educação Nacional (LDBEN) (BRASIL, 1996), no que diz respeito à formação dos profissionais da educação, afirma que:

A formação de docentes para atuar na educação básica far-se-á em nível superior, em curso de licenciatura, de graduação plena, em universidades e institutos superiores de educação, admitida, como formação mínima para o exercício do magistério na educação infantil e nas quatro primeiras séries do ensino fundamental, a oferecida em nível médio, na modalidade Normal (BRASIL, 1996, p. 26).

Assim, podemos constatar que a formação interdisciplinar por área de conhecimento não é negada pela legislação educacional, mas, pelo contrário, é tida como 


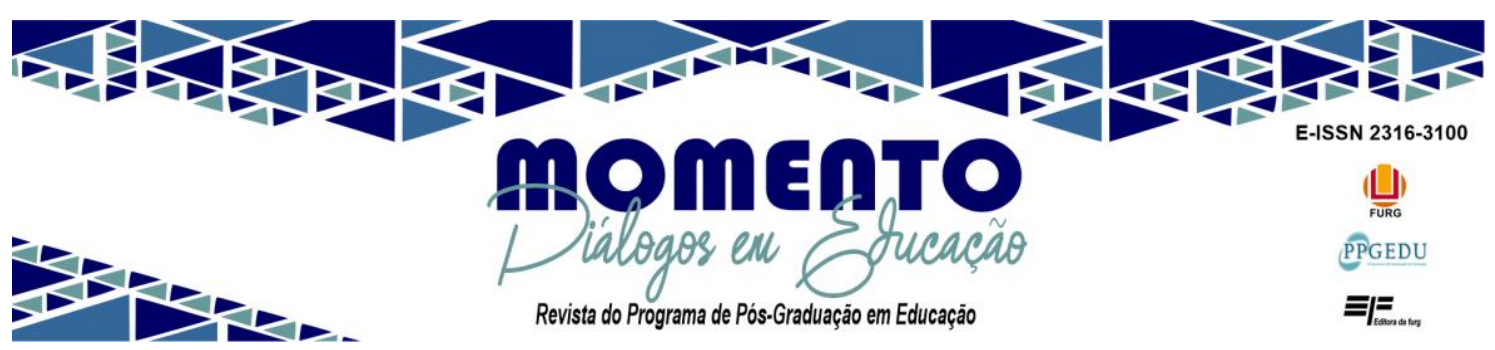

possibilidade. Todavia, como visto, na realidade do Estado do Paraná, essa formação propiciada pelo Curso de Licenciatura em Educação do Campo ainda não é efetivamente reconhecida.

No contexto do marco legal da educação no Brasil, o Decreto $N^{\circ} 7.352$, de 4 de novembro de 2010, ao dispor sobre a política de Educação do Campo, alcança importante destaque na afirmação desta como política pública:

\begin{abstract}
A política de educação do campo destina-se à ampliação e qualificação da oferta de educação básica e superior às populações do campo, e será desenvolvida pela União em regime de colaboração com os Estados, o Distrito Federal e os Municípios, de acordo com as diretrizes e metas estabelecidas no Plano Nacional de Educação e o disposto neste Decreto. (BRASIL, 2010).
\end{abstract}

De acordo com a Carta de Reconhecimento das Licenciaturas em Educação do Campo (UFPR et al., 2017), somente no ano de 2017, mais de cinquenta Instituições de Educação Superior públicas no Brasil ofertavam este tipo de curso de graduação, sendo que, conforme já mencionado, cinco dessas Universidades localizavam-se no Estado do Paraná. Analisando tais números, percebe-se a amplitude do posicionamento de negação ao reconhecimento do diploma em Licenciatura em Educação do Campo no Paraná, sendo essa uma questão que afeta, diretamente, a educação dos povos trabalhadores do campo, em especial, a realidade da escola do campo.

Ao analisar a Ata $\mathrm{n}^{\circ}$ 01/2018 (UFFS, 2018) e os argumentos apresentados pela SEED-PR, é possível constatar a falta de conhecimento a respeito da formação possibilitada no Curso de Licenciatura em Educação do Campo e do próprio aparato legal que lhe dá sustentação. Como dito, no ano de 2013, quatro egressas e egressos do Curso de Licenciatura em Educação do Campo, ofertado pela UNICENTRO, foram aprovados no concurso público realizado pela SEED-PR, contudo foram impedidos de assumir o cargo. A justificativa apresentada foi que a formação dos candidatos era por área de conhecimento, sendo que só seriam validados diplomas em que se constatasse a formação disciplinar. Ainda de acordo com a Ata nº1/2018 (UFFS, 2018), no ano de 2018, alguns candidatos ao edital do Processo Seletivo Simplificado (PSS) (PARANÁ, 2017) foram impedidos de assumirem aulas nas escolas do campo. 


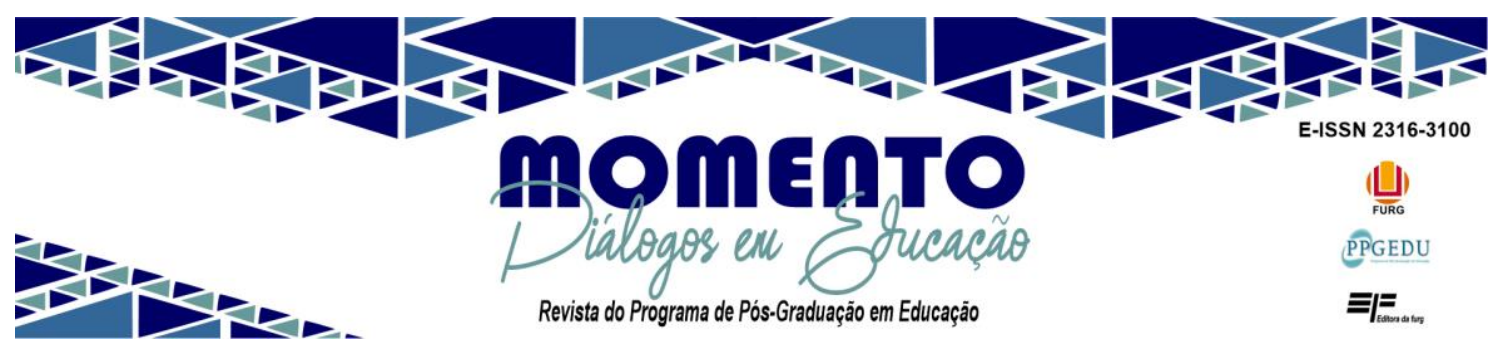

Analisando o Edital no 72/2017-GS-SEED (PARANÁ, 2017), que foi publicado sob a responsabilidade da SEED-PR para seleção e contratação de professores PSS para atuarem, a partir do ano de 2018, na rede pública estadual de educação, constata-se uma discriminação em relação aos profissionais formados em Educação do Campo, pois a pontuação de quem era licenciado por área de conhecimento considerava cinco pontos a menos do que os candidatos que tinham licenciatura com formação disciplinar.

Quadro 2 - Diferença de pontuação no PSS 2018 - edital 72/2017-GS-SEED Paraná, 2017

\begin{tabular}{|l|c|}
\hline \multicolumn{1}{|c|}{ PSS 2018 - ETAPA 10 - EDUCAÇÃO DO CAMPO - PROFESSOR DAS DISCIPLINAS DOS } \\
ANOS FINAIS DO ENSINO \\
\multicolumn{1}{|c|}{ FUNDAMENTAL, ENSINO MÉDIO E EJA - Código 201762} \\
\hline \multicolumn{1}{|c|}{ ESCOLARIDADE OBRIGATÓRIA } & Pontos \\
\hline $\begin{array}{l}\text { a) Diploma de licenciatura plena ou bacharelado, } \\
\text { acompanhado de certificado de formação } \\
\text { pedagógica na disciplina de inscrição }\end{array}$ & 75 \\
b) Diploma de licenciatura em Educação do \\
$\begin{array}{l}\text { Campo, com habilitação na disciplina de } \\
\text { inscrição }\end{array}$
\end{tabular}

Fonte: Paraná, 2017.

Essa compreensão da discriminação do Estado frente à formação em Educação do Campo e por áreas de conhecimento, traduzida no Edital no 72/2017-GS-SEED (PARANÁ, 2017), foi amplamente identificada e problematizada na Audiência Pública dos Cursos de Licenciaturas em Educação do Campo. No depoimento realizado na Audiência, a egressa da UNICENTRO afirmou que "[...] no edital de PSS a pontuação do diploma em Educação do Campo tem nota menor e na distribuição de aulas são prejudicados em relação aos candidatos com formação em disciplina." (UFFS, 2018, p. 2). Nesta mesma Audiência, foram pautadas: a necessidade de reconhecimento do curso, a revisão dos editais quanto à pontuação e à valorização no plano de carreira com o pagamento (UFFS, 2018, p. 2).

Tendo como referência a conquista efetivada no Estado de Santa Catarina (SANTA CATARINA, 2016), a Audiência Pública (UFFS, 2018) indicou, ainda, a necessidade de publicação de uma Nota Técnica a ser elaborada pela SEED-PR, reconhecendo, de maneira inequívoca, o Curso de Licenciatura em Educação do Campo, por área de conhecimento no Estado, tanto para fins do PSS como de concurso público 


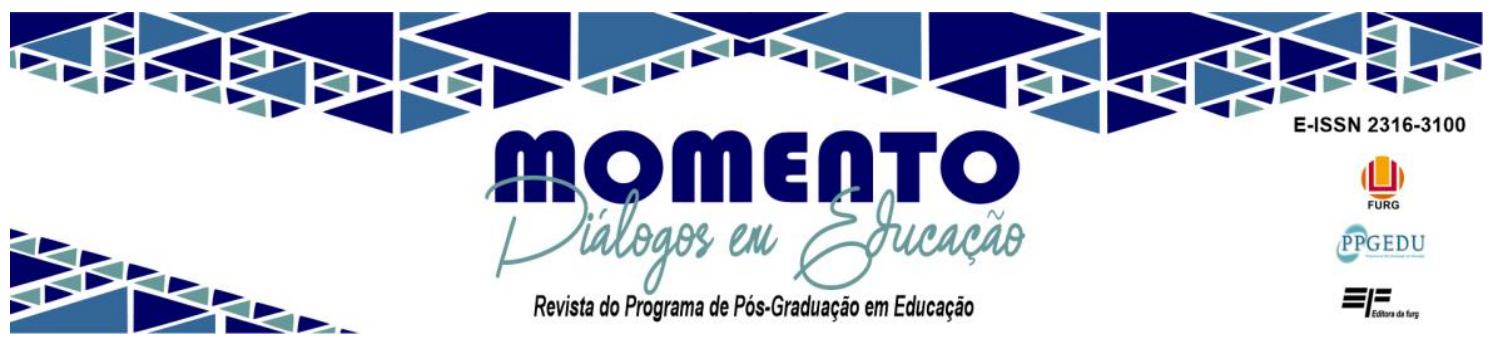

para o magistério na rede pública estadual de educação. Um dos principais elementos em tal situação e sustentadores dessa reivindicação é a contradição posta na existência de cursos superiores devidamente reconhecidos pelo MEC e ofertados por Universidades Federais e Estaduais, que, financiados pelo recurso público, são negados pelo próprio Estado, no caso aqui posto, pela SEED-PR.

Já no ano de 2018, após os vários processos de reivindicação e negociação acerca do reconhecimento do Curso de Licenciatura em Educação do Campo, concretizados no Paraná, algumas mudanças foram verificadas no edital do PSS (PARANÁ, 2018). Essas mudanças trouxeram mais condições aos egressos em Educação no Campo quanto à possibilidade de assumir aulas na rede pública estadual de educação. Uma das mudanças mais significativas foi a equiparação da pontuação dos egressos em Educação do Campo, que, antes da alteração, pontuavam apenas 70 pontos. Agora, com a mudança, os mesmos foram igualados aos demais professores que cursaram licenciaturas com formação disciplinar, pontuando, ambos, 75 pontos (PARANÁ, 2018).

Como conquista parcial referente a essa mudança, no edital do PSS (PARANÁ, 2018), segundo informações do Núcleo Regional de Educação (NRE) de Laranjeiras do Sul (UFFS, 2019), a partir do edital PSS (PARANÁ, 2018), para o ano letivo de 2019, foram 27 contratos abertos e ocupados por profissionais com formação em Educação do Campo nas escolas de abrangência daquele NRE.

Dos contratos efetivados no NRE de Laranjeiras do Sul, vinte profissionais tiveram ou estão tendo sua formação propiciada pelos cursos ofertados na UFFS, Campus Laranjeiras do Sul. Em suma, são acadêmicas e acadêmicas que cursam as fases finais e, também, profissionais egressos da Licenciatura em Educação do Campo. Dos vinte profissionais contratados, onze são docentes formados ou em formação no Curso Interdisciplinar em Educação do Campo: Ciências Naturais e Matemática e Ciências Agrárias - Licenciatura e nove são do Curso Interdisciplinar em Educação do Campo: Ciências Sociais e Humanas - Licenciatura. Esses dados indicam a efetividade da reivindicação sobre o reconhecimento pleno do profissional docente formado na Educação do Campo por áreas de conhecimento no Paraná e, também, a atualidade dessa reivindicação. 


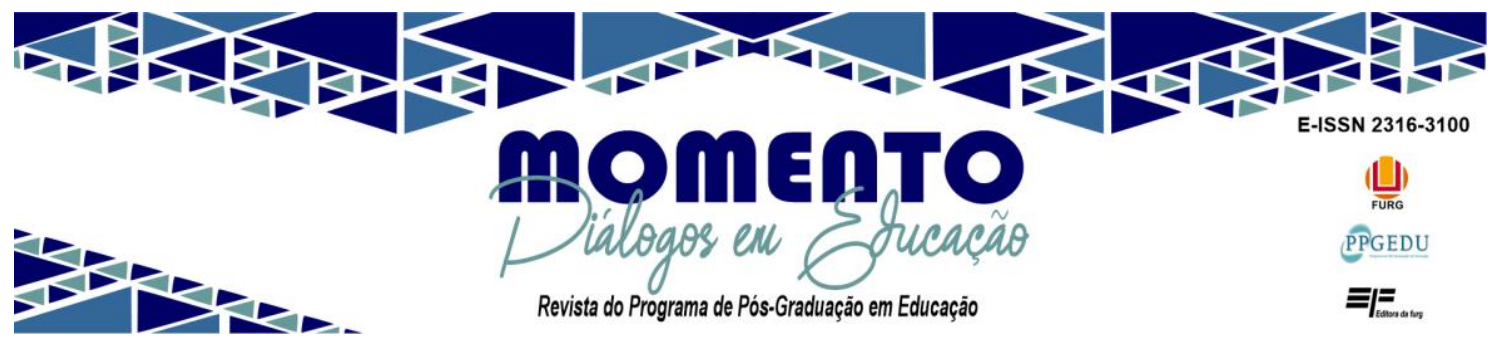

\section{Considerações finais}

A sistematização dessa elaboração coloca-se como parte de um processo contínuo de luta e afirmação da Educação do Campo como direito dos povos trabalhadores do campo e como dever do Estado. Assim, a análise apresentada não é algo pronto e acabado, mas integra uma demanda atual da classe trabalhadora camponesa materializada nas lutas protagonizadas pelos Movimentos Sociais e pelas Organizações Populares do Campo, que, além de reivindicarem o direito à terra, buscam o direito à educação.

A pesquisa em questão buscou pontuar alguns dos desafios que as egressas e os egressos do Curso de Licenciatura em Educação do Campo estão enfrentando no que se refere à sua inserção profissional como docentes na rede pública de educação, no Estado do Paraná. Somado a isso, o trabalho evidenciou a expansão dos Cursos de Licenciatura em Educação do Campo e registrou que, no Estado do Paraná, o Curso contou e conta com a oferta em cinco Universidades públicas, sendo elas: a UNIOESTE, a UNICENTRO, a UTFPR, a UFPR e a UFFS. Destaca-se que, até o primeiro semestre de 2019, essas cinco Universidades formaram um contingente de 227 licenciadas e licenciados em Educação do Campo nas mais diversas áreas do conhecimento.

Entre os elementos apresentados no decorrer da análise, foram examinadas algumas conquistas relacionadas ao paradigma da Educação do Campo, principalmente, no âmbito das políticas públicas, e, em especial, na formação de professores por meio do PROCAMPO.

Todavia, também foram identificados vários desafios, sendo aprofundado o que diz respeito ao não reconhecimento da titularidade do profissional graduado na Licenciatura em Educação do Campo no Paraná.

Nesse sentido, foram apresentadas algumas situações concretas que expressam a negação do direito ao exercício da profissão docente às licenciadas e aos licenciados em Educação do Campo no Paraná. E, ao mesmo tempo, apontou-se para a necessidade de mobilização junto aos Movimentos Sociais e às Organizações Populares do Campo, para que tal reivindicação tome fôlego e seja considerada pelo Estado.

Em conexão com o processo de mobilização dos povos trabalhadores do campo afirmado como materialidade de origem da Educação do Campo -, foram organizadas 


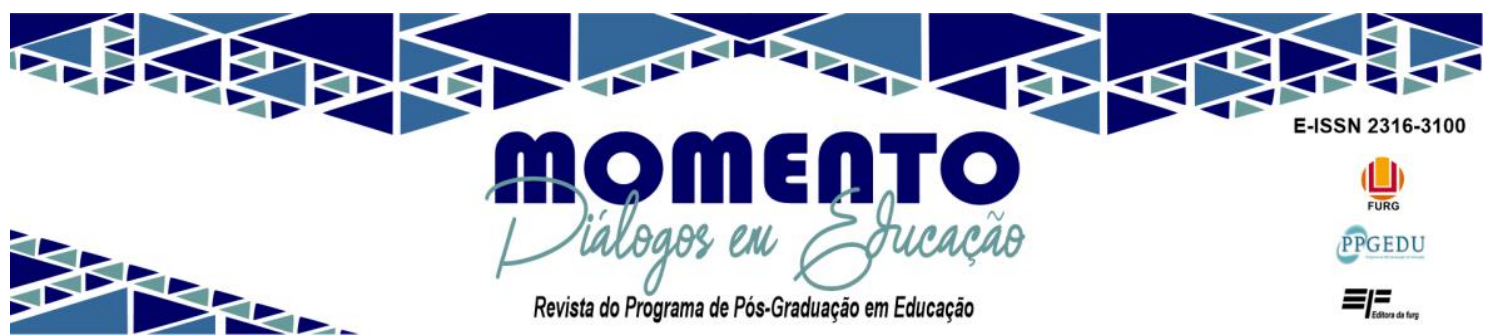

Audiências Públicas para tratar do reconhecimento dos profissionais licenciados em Educação do Campo no Estado do Paraná.

Como fruto dessa mobilização, já no PSS vinculado ao Edital no 57/2018 GS/SEED, sob responsabilidade da SEED-PR, que teve por objetivo a seleção de professores para atuar na rede pública estadual de educação a partir do ano de 2019, foi conquistada a equiparação entre os profissionais graduados em Educação do Campo e por área do conhecimento e os demais profissionais graduados por disciplinas.

Deste modo, o trabalho e a análise efetivados colocam-se como expressão da conjuntura atual, reflexo das contradições econômicas, sociais e políticas postas na sociedade brasileira. Como parte deste processo, a luta por uma Educação do Campo, para sua afirmação e continuidade, tem um longo caminho a percorrer, o que exigirá momentos de mobilizações e reivindicação para garantia do direito à educação, à terra e à qualidade de vida.

A luta por uma Educação do Campo implica a luta pelo direito à vida no campo, pelo direito à produção da existência como camponeses e camponesas. Sendo assim, é crível a necessidade de seguir resistindo e lutando por uma sociedade mais justa, em que a Educação do Campo contribua para essa construção. Portanto, coloca-se como dever histórico dar continuidade a este processo, tendo em vista que este projeto de educação materializou-se por meio de uma demanda social e política de povos que, muitas vezes, tiveram seu acesso à educação negado e, em especial, à Educação Superior. Mas, por meio de sua capacidade de mobilização, de organização e de luta, esses povos trabalhadoras e trabalhadores do campo - têm alcançado as condições de ocupar o espaço que lhes é de direito, também, na Universidade.

Portanto, afirma-se a compreensão de que a Licenciatura em Educação do Campo, como elemento intrínseco à luta por uma Educação do Campo, é uma das maneiras de os povos trabalhadores do campo ocuparem a Universidade, o que a coloca como uma importante política de inclusão. Contudo, suas possibilidades de afirmação e de continuidade mantêm vínculos concretos com a materialidade de origem da luta por uma Educação do Campo. Sendo assim, a garantia do reconhecimento do profissional docente licenciado em Educação do Campo, por áreas de conhecimento, coloca-se como elemento fundamental, pois mesmo a inclusão dos povos trabalhadores do campo na Educação 


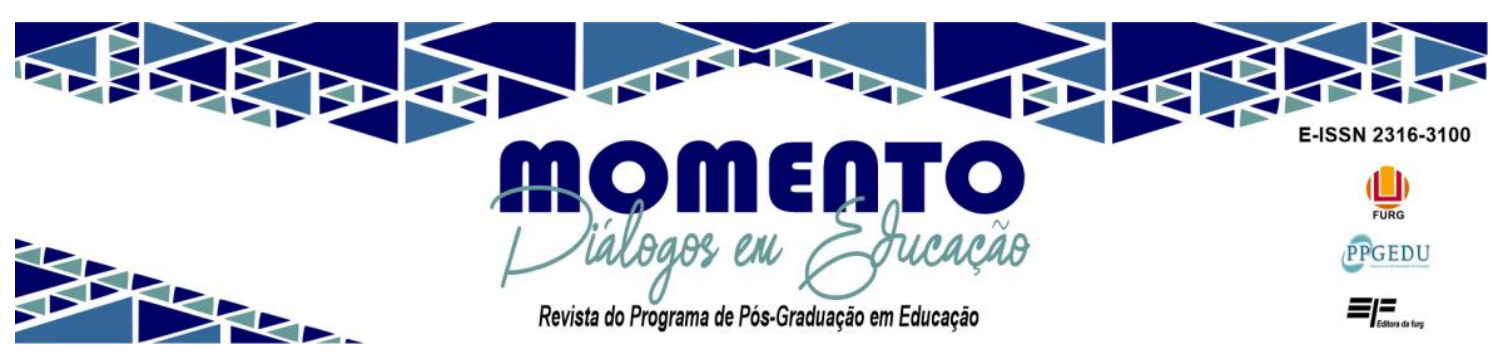

Superior que a Licenciatura em Educação do Campo promoveu pode estar ameaçada com o não reconhecimento da titularidade propiciada pelo Curso.

Desse modo, a conexão direta dessa demanda com a luta por uma Educação do Campo e a afirmação e do marco legal da política pública de Educação do Campo são fatores fundamentais para viabilizar as políticas de inclusão na contemporaneidade, combatendo, sobremaneira, processos de exclusão e retirada de direitos intentados nesse momento complexo vivenciado pela sociedade brasileira.

Ademais, registra-se a conexão direta do reconhecimento e a possibilidade de atuação profissional das egressas e dos egressos da Licenciatura em Educação do Campo como elemento de fundamental importância na afirmação e no delineamento da escola do campo.

É crível a importância da escola como agência formadora em nossa contemporaneidade. Por isso, uma das questões latentes postas pela Educação do Campo diz respeito à necessária conexão entre a escola e as múltiplas agências formadoras que integram e constituem a concretude das comunidades camponesas. Isso, na proposição de Freitas (2010, p. 158), implica compreender a vida como referência primeira, ou seja, tomar o trabalho em seu sentido ontológico de atividade eminentemente humana, por meio do qual é produzida e reproduzida a existência - a vida humana - em todas suas dimensões.

Assim, a atuação profissional da licenciada ou do licenciado em Educação do Campo, no contexto das escolas do campo, coloca-se como potencial na busca por essa conexão entre a escola e a realidade concreta produzida por meio do trabalho, que é o sustentador da vida em todas suas dimensões. Nesse aspecto, coloca-se o perfil formativo possibilitado na Licenciatura em Educação do Campo, que, estruturado sob o regime de alternância e na formação por áreas de conhecimento, passa a ser impulsionado pela própria identidade e pertença desses sujeitos as suas comunidades de inserção e as agências formadoras que a integram, seja a luta nos Movimentos Sociais e nas Organizações Populares do Campo, seja a luta por uma Educação do Campo, bem como os processos formativos desenvolvidos nesses contextos, dentre eles, os que se vinculam à escola. 


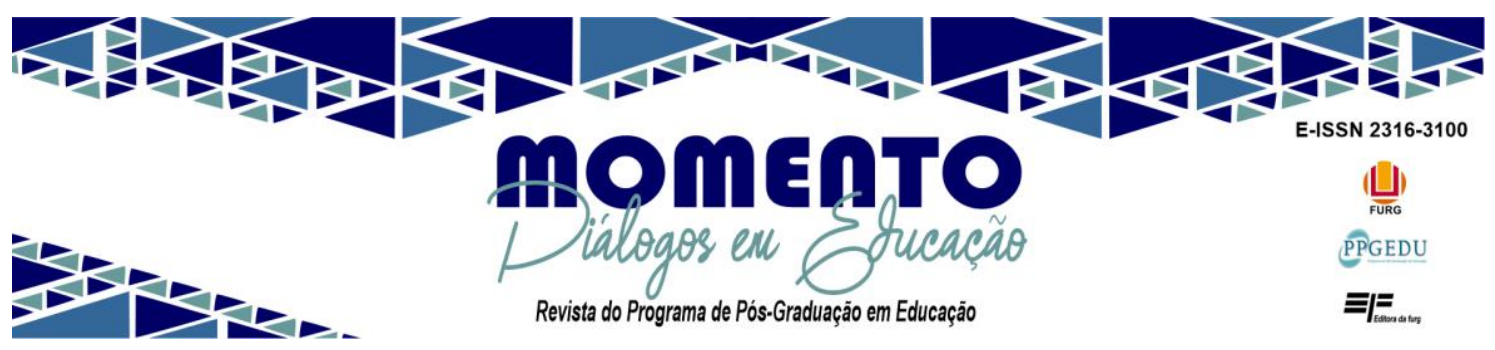

Referências

BRASIL. Lei das Diretrizes e Bases da Educação. Lei $\mathbf{n}^{\circ}$ 9.394. 1996. Disponível em: https://www2.senado.leg.br/bdsf/bitstream/handle/id/70320/65.pdf. Acesso em: 26/01/2019.

Decreto Presidencial $n^{0}$ 7.352, de 4 de novembro de 2010. Disponível em: http://portal.mec.gov.br/docman/marco-2012-pdf/10199-8-decreto-7352-de4-denovembro-de-2010/file. Acesso em: 29/01/2019.

. Ministério da Educação. Ações do PRONACAMPO: Formação Inicial e Continuada de Professores. 2021. Disponível em: http://pronacampo.mec.gov.br/14acoes-do-pronacampo/10-formacao-inicial-e-continuada-de-professores. Acesso em: $17 / 02 / 2021$.

CALDART, R. S. Sobre Educação do Campo. Educação do Campo: reflexões a partir da tríade Produção - Cidadania - Pesquisa. In: SANTOS, C. A. dos (Org.). Por uma Educação do Campo: Campo - Políticas Públicas - Educação. Brasília: INCRA; MDA, 2008. (Coleção Por uma Educação do Campo n ${ }^{\circ}$ 7).

Educação do Campo: Notas para uma Análise de Percurso. Revista Científica da EPSJV/Fiocruz, Trabalho, Educação e Saúde. Rio de Janeiro, v.7, n.1, pp. 35-64, mar./jun. 2009.

CEAGRO - Centro de Desenvolvimento Sustentável e Capacitação em Agroecologia. Audiência Pública debate carreira dos licenciados em Educação do Campo. 2 de julho de 2018. Disponível em: http://www.ceagro.org/index.php/tag/educacao-docampo/. Acesso em: 29/10/2019.

FARIAS, M; FALEIRO, W. Rompendo as cercas da Universidade: a Educação do Campo na UFG - Catalão/GO. Catalão, GO: Novas Edições Acadêmicas, 2017.

FREITAS, L. C. de. A Escola Única do Trabalho: explorando os caminhos de sua construção. In: CARDART, R. S. et al. (Orgs.). Caminhos para transformação da escola: reflexões da Licenciatura em Educação do Campo. São Paulo: Expressão Popular, 2010, pp. 155-175. (Cadernos do ITERRA, ano 10, $\mathrm{n}^{\circ} .15$ ).

FERNANDES, B.M. A territorialização do MST- Movimento dos Trabalhadores Rurais Sem Terra - Brasil. Ano 1, n. 1 p. 2 - 44, 1998.

KUHN, E. R. A. Análise da política de Educação do Campo no Brasil: Meandros do Pronera e do Pronacampo. 2015. 144 f. Tese (Doutorado em Análise do Espaço Geográfico) - Universidade Federal da Bahia, Salvador, 2015.

LEHER, R. Guerra cultural e Universidade pública: o Future-se é parte da estratégia de silenciamento. In: GIOLO, J.; LEHER, R.; SGUISSARDI, V. (Orgs.). Future-se: ataque à autonomia das instituições federais de educação superior e sua sujeição ao mercado. São Carlos: Diagrama Editorial, 2020. p. 106-149.

LIMA, A. G. A Pedagogia da Alternância no Curso Interdisciplinar Ciências Sociais e Humanas da Universidade Federal da Fronteira Sul: Limites e Potencialidades. - 


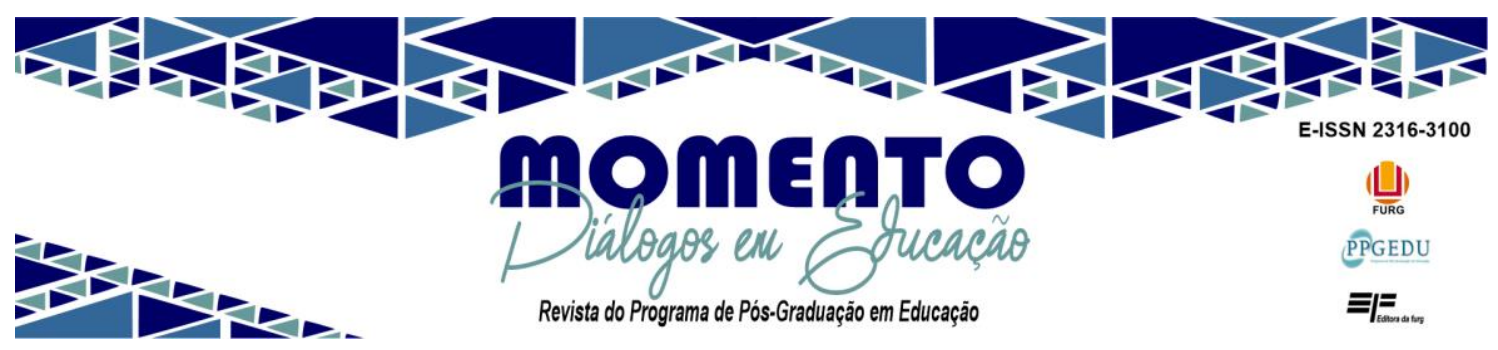

2017. 64 f. Trabalho de Conclusão de Curso (Curso Interdisciplinar em Educação do Campo: Ciências Sociais e Humanas - Licenciatura), Universidade Federal da Fronteira Sul, Campus Laranjeiras do Sul, 2017.

MEC - Ministério da Educação. Secretaria de Educação Continuada, Alfabetização, Diversidade e Inclusão - Apresentação. 2019. Disponível em: http://portal.mec.gov.br/secretaria-de-educacao-continuada-alfabetizacao-diversidade-einclusao/apresentacao. Acesso em: 16/10/2019.

MOLINA, M. C. Reflexões sobre o significado do protagonismo dos movimentos sociais na construção de políticas públicas de Educação do Campo. In: MOLINA, M. C.(org). Educação do Campo e Pesquisa II: questões para reflexão. Brasília: MDA/MEC, 2010.

MOLINA, M. C.; ANTUNES-ROCHA, M. I. Educação do Campo: história, práticas e desafios no âmbito das políticas de formação de educadores - reflexões sobre o PRONERA e o PROCAMPO. Revista Reflexão e Ação, v. 22, n. 2, p. 220-253, jul./dez. 2014. Disponível em: https://online.unisc.br/seer/index.php/reflex/article/view/5252. Acesso em: 17/02/2021.

PARANÁ. Resolução $\mathbf{n}^{\mathbf{0}}$ 4783, 28 de outubro de 2010. Disponível em: https://www.legislacao.pr.gov.br/legislacao/pesquisarAto.do?action=exibir\&codAto $=69$

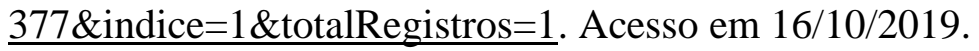

Edital $\mathbf{n}^{\mathbf{0}}$ 017/2013, 18 de fevereiro de 2013. Disponível em: https://www.pucpr.br/wp-content/uploads/2018/02/edital-017-2013-seedmagisterio.pdf. Acesso em: 16/10/2019.

Edital no 72/2017 - GS/SEED, 15 de dezembro de 2017. Disponível em: http://www.educacao.pr.gov.br/arquivos/File/editais/2017/edital722017gsseed.pdf. Acesso em: 16/10/2019.

Edital no 57/2018 - GS/SEED, $1^{\circ}$ de outubro de 2018. Disponível em: http://www.nre.seed.pr.gov.br/modules/qas/uploads/3564/edital_57_pss_professor_201 9_versao_final.pdf. Acesso em: 16/10/2019.

SANTA CATARINA. Nota Técnica Conjunta n⿳ 3/2016 (SED/DIGR/DIGP), 13 de dezembro de 2016. Florianópolis: Secretaria de Estado da Educação, 2016.

SANTOS, C. A. dos. A Licenciatura em Educação do Campo. In: Educação do Campo e políticas públicas no Brasil: o protagonismo dos movimentos sociais do campo na instituição de políticas públicas e a licenciatura em educação do campo na UnB. Brasília: Liber Livro; Faculdade de Educação/ Universidade de Brasília, 2012.

STÉDILE, J. P. A Questão Agrária no Brasil: o debate na esquerda. São Paulo: Expressão Popular, 2005.

UFFS - Universidade Federal da Fronteira Sul, Campus Laranjeiras do Sul. Ata $\mathbf{n}^{\mathbf{0}}$ 01/2018 da Audiência Pública dos Cursos de Licenciaturas em Educação do Campo, 28 de junho de 2018. Laranjeiras do Sul: UFFS, 2018.

Cursos de Educação do Campo possibilitam a inserção profissional de seus acadêmicos e egressos. 21 de março de 2019. Disponível em: 


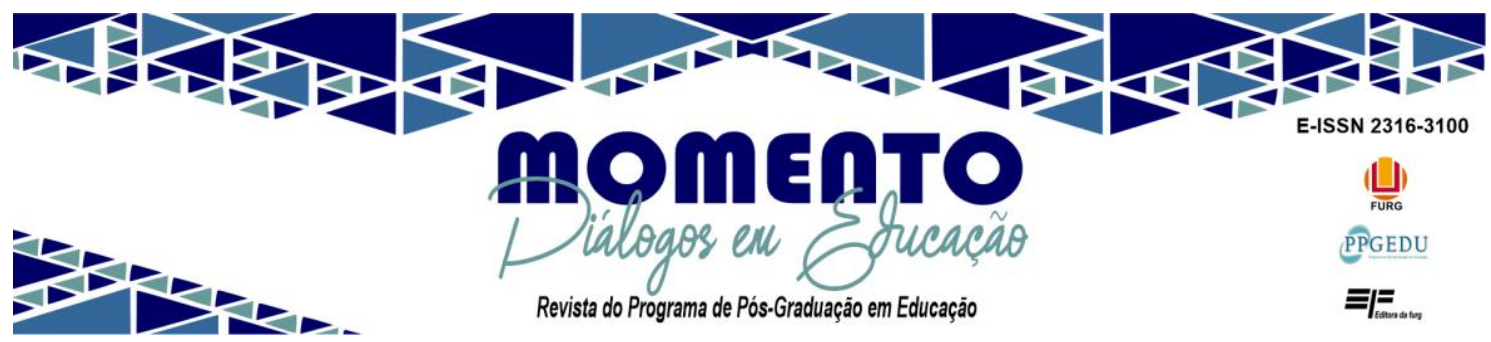

https://www.uffs.edu.br/campi/laranjeiras-do-sul/noticias/cursos-de-educacao-docampo-da-uffs-tem-possibilitado-a-insercao-profissional-de-seus-academicos-eegressos. Acesso em: 16/10/2019.

UFPR - Universidade Federal do Paraná, Setor Litoral et al. Carta pelo reconhecimento da Licenciatura em Educação do Campo. - Curitiba, 2017 (Documento não público)

VERDÉRIO, A. A pesquisa em processos formativos de professores do campo: a Licenciatura em Educação do Campo na UNIOESTE (2010 - 2014). 2018. Tese (Doutorado) - Programa de Pós-Graduação em Educação da Universidade Federal do Paraná, Curitiba, 2018. Disponível em: https://acervodigital.ufpr.br/handle/1884/59470. Acesso em: 24/04/2019.

VERDÉRIO, A. et al. Setores Populares na Universidade Pública: a experiência da UNIOESTE na interface Educação Superior e Educação do Campo. Cascavel, 2019. (Documento não público).

Submissão em: 29-10-2019

Aceito em: 22-03-2021 